\title{
ANALYSIS OF THE EFFECT OF FINANCIAL RATIO ON FINANCIAL DISTRESS CONDITIONS IN MANUFACTURING COMPANIES LISTED IN INDONESIA STOCK EXCHANGE
}

\author{
Normiati $^{1)}$ dan Diah Amalia ${ }^{2)^{*}}$ \\ Politeknik Negeri Batam \\ Managerial Accounting Study Program \\ Jl. Ahmad Yani, Batam Centre, Batam 29461, Indonesia \\ 1)e-mail: nurminurr@gmail.com \\ ${ }^{2)}$ e-mail: diahamalia@polibatam.ac.id
}

\begin{abstract}
This study aims to analyze any indicators in financial ratios that affect financial distress conditions. The data used are data on manufacturing companies in the Indonesia Stock Exchange (IDX) in 2012-2017, which are as many as 80 samples. Dependent financial distress variables are measured using the Altman analysis model (Z-Score). Independent variables are measured using the financial ratios indicator. This study uses a non-probability sampling technique that is purposive sampling. The data used is panel data, using Eviews 9. The results of this study show that the liquidity ratio measured by the current ratio and the leverage ratio measured by the debt asset ratio affect the condition of financial distress. While the profitability ratio measured by return on assets and sales growth does not affect the financial ratio. This research contributes to investors who can use this model, by including the financial ratios indicator, to assess the financial health of the company before making investment-related decisions.
\end{abstract}

Keywords: Financial Distress, Financial Ratios, Intellectual Capital, Z-Score

\begin{abstract}
ABSTRAK
Penelitian ini bertujuan untuk menganalisis indikator-indikator apa saja dalam financial ratios yang mempengaruhi kondisi financial distress. Data yang digunakan yaitu data perusahaan manufaktur di Bursa Efek Indonesia (BEI) tahun 2012-2017 yakni sebanyak 80 sampel. Variabel dependen financial distress diukur dengan menggunakan model analisis Altman (Z-Score). Variabel independen diukur menggunakan indikator financial ratios. Penelitian ini menggunakan teknik sampel non-probability sampling yaitu purposive sampling. Data yang digunakan adalah data panel, dengan menggunakan Eviews 9. Hasil dari penelitian ini menujukkan bahwa rasio likuiditas yang di ukur dengan current ratio dan rasio leverage yang diukur dengan debt asset ratio berpengaruh terhadap kondisi financial distress. Sedangkan rasio profitabilitas yang diukur dengan return on asset dan pertumbuhan penjualan tidak berpengaruh terhadap financial ratio. Penelitian ini berkontribusi bagi investor yang dapat menggunakan model ini, dengan memasukkan indikator financial ratios, untuk menilai kesehatan keuangan perusahaan sebelum membuat keputusan terkait investasi.
\end{abstract}

Kata kunci: Financial Distress, Financial Ratios, Intellectual Capital, Z-Score

*Corresponding author. E-mail: diahamalia@polibatam.ac.id 


\section{INTRODUCTION}

In general, every company was founded with the aim of obtaining maximum profits in order to support long-term survival and not improve liquidation. Upon receipt, it is hoped that this will not need to be done in accordance with what is desired. Changes to Expected Performance Towards an increase in corporate finances, first for national scale companies. This is what requires companies to improve their financial and financial accountability, if management does not support it well, then the shadow of financial improvement will require companies (Liana and Sutrisno, 2014). Companies that continue to experience a decline in performance are feared to experience financial difficulties (Khaliq et al, 2014). Therefore, information about financial difficulties can be done early for management to act quickly and appropriately to resolve the issue before bankruptcy.

The phenomenon of financial difficulties experienced by companies, usually characterized by the increasing ability of the company to meet its long-term requirements (Hanifah, 2013). In addition, companies categorized as experiencing financial distress are companies that are improving this book value, operating profit and negative profit (Brahmin, 2007). A series of mistakes can also cause changes in financial distress conditions, such as decreasing accuracy in decision making, and minimizing efforts to improve the company's financial condition, thereby increasing the appropriateness of the use of funds with what is needed by the company (Brigham and Daves, 2003).

Analysis using financial ratios (financial ratios) is one of the most frequently used analyzes in predicting financial distress. This research was first carried out by Altman (1968), this became an interesting topic after the discovery of a formula to facilitate company bankruptcy using the
Altman Z-Score model. Furthermore, many researchers use financial ratios (financial ratios) to be analyzed and become bankruptcy prediction models. According to Khaliq et al (2014) financial ratios are important in analyzing companies and which improves companies through application practices.

The Researchers who developed bankruptcy prediction models recognize that financial ratios are one of the means of predicting financial distress because financial ratios can reflect the financial condition of a company (Lakhsan and Wijekoon, 2013). Given the importance of financial ratio analysis on the prediction of a company's financial distress, several studies have been conducted before.

Based on research conducted by Lakhsan and Wijekoon (2013), it shows that debt ratio, working capital to total asset ratio, and cash flow from operating activities to total assets have a significant effect on the prediction of a company's financial distress. The results of Baimwera and Muriuki's research (2014), strengthen previous research which illustrates that there is no significant effect between leverage ratios and liquidity ratios to financial distress. While a significant influence is shown by the variable sales growth and profitability ratios to a company's financial distress.

This research is a replication of a study conducted by Baimwera and Muriuki (2014), the difference of this study with previous research that is found in the period, company samples and research sites. Based on this description, researchers are interested in constructing a research model that can test the effect of leverage ratios, liquidity ratios, sales growth and profitability ratios on the prediction of financial distress.

\section{Formulation Of The Problem}

Based on the background description above, the formulation of the problem in this 
study is how financial ratios affect the financial distress condition in the manufacturing industry sector which is listed on the Indonesia Stock Exchange (BEI) in 2012-2017.

\section{Theoretical Basis}

\section{Agency Theory}

This theory argues that there are differences in interests between the two interrelated parties namely the principal and the agent. Principal is defined as a party that gives a mandate to another party called an agent, in this case the principal is a shareholder or shareholder while management becomes the agent. This agency theory arises because of the occurrence of a contract between the principal and agent to manage the company and hand over authority to the agent in making decisions. The agency problem arises because of a conflict of interest between the two parties. There is an opportunity for the agent to maximize personal welfare that is contrary to the interests of the principal by limiting the information provided about the company to the principal (Jensen \& Meckling, 1976).

\section{Financial Distress}

Platt and Platt (2002) suggest that financial distress is one of the stages in the decline of financial conditions before bankruptcy occurs. Bankruptcy is a condition that shows the company's inability to fulfill all the obligations of lenders (debtors) due to the lack of funds owned by the company to run and continue its business so that the achievement of economic goals is not fulfilled (Wongsosudono, 2013). When financial difficulties occur, the lack of working capital or company working capital is indicated by the company's inability to fulfill its obligations (Aghaei, 2013).

Baimwera and Muriuki (2014) also define the same thing about financial distress. Inadequate working capital can be caused by several factors, such as operating costs and current liabilities that are too high. Companies that experience financial distress without further action to improve, then the company is threatened with bankruptcy and even liquidated.

\section{Financial Reports and Financial Ratios}

According to the definition set forth in Statement of Financial Accounting Standards (PSAK) No. 1, that financial statements are a structured presentation of the financial performance and financial position of an entity. Financial reports can be a source of information that can be useful in making decisions about investment and funding. As stated in Statement of Financial Accounting Standards (PSAK) No. 1 that the purpose of the financial statements is to provide information related to the financial position, performance and cash flow of the company that can be used in making economic decisions for its users.

Almilia and Kristijadi (2003), states that most researchers use financial statements to be analyzed and explain financial distress predictions. Financial ratios through financial statement analysts are used to measure a company's financial distress (Hapsari, 2012). Analysis of financial ratios will give an analysis to analysts about the good or bad financial performance (Munawir, 1999)

\section{HYPOTHESIS DEVELOPMENT}

\section{The Relationship Between Liquidity Ratios and Financial Distress}

Based on previous research from Atika, et al (2012) shows that the liquidity ratio (current ratio) has a significant negative effect on the likelihood of financial distress in a company. This shows the inverse relationship between the independent variable and the dependent variable. If the 
intensity of the company's ability to meet its short-term obligations is getting higher, then the possibility of financial distress will be even greater. Different results were obtained through research results from Nurhidayah and Fitriyatur (2017), showing the positive influence of the variable Liquidity on financial distress, using Current Ratio (CR) as a tool to measure it. Based on the description above, the research hypothesis proposed is:

H1: Liquidity Ratio has a positive influence on financial distress.

\section{The Relationship Between Leverage Ratio and Financial Distress}

Research conducted by Ahmad (2011), shows that leverage ratios significantly have positive implications for financial distress in a company when measured using Debt to Asset Ratio (DAR). This shows the relationship that is directly proportional between the independent variable and the dependent variable. If the intensity of the use of debt in funding the company is getting bigger, then the possibility of financial distress will be even greater. Based on the description above, the research hypothesis proposed is:

H2: Leverage Ratio has a positive influence on financial distress.

\section{The Relationship Between Profitability Ratios and Financial Distress}

Previous research states that Return On Assets (ROA) has a significant negative effect on financial distress, which means that the higher the profits derived by a company, the smaller a company will experience financial distress (Hapsari, 2012). In contrast to research conducted by Nurhidayah and Fitriyatur (2017), the results of his study indicate that the profitability variable measured by Return On Investments (ROA) and Net Profit Margin (NPM) has a positive effect on Financial distress. Based on the description above, the research hypothesis proposed is:

H3: Profitability Ratio has a negative effect on financial distress.

\section{Relationship Between Sales Growth and Financial Ratio}

Based on the results of previous studies, it is stated that sales growth has a significant negative effect on financial distress (Eliu, 2014). This means that the lower the level of sales growth of a company, the higher the possibility of financial distress experienced by the company. Meanwhile, if the intensity of sales growth is higher, the potential for companies to experience financial distress will be smaller. Based on the description above, the research hypothesis proposed is:

H4: Sales growth has a negative influence on financial distress.

H5: Liquidity ratios, leverage ratios, profitability ratios and sales growth have an influence on financial distress

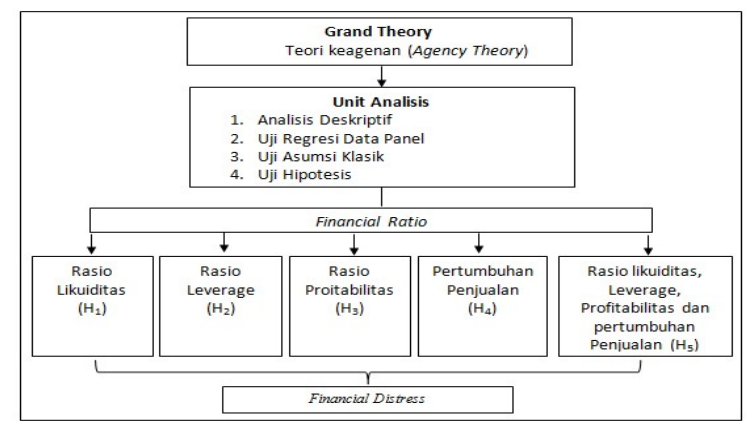

Figure 1 Research Framework Source: Author

\section{RESEARCH METHOD}

The method used in this research is to use a quantitative approach. The author uses a quantitative approach as a research method for reasons, because this research was conducted by collecting and analyzing data presented in the financial statements then expressed in calculations that show the value of the variables they represent. 


\section{Operational Variables and Measurements}

\section{FINANCIAL RATIO}

\section{Liquidity Ratio}

The liquidity ratio shows the company's ability to meet its short-term obligations when billed. Liquidity ratios are also needed for the purposes of credit analysis or financial ratio analysis. The high liquidity ratio shows the company's ability to pay its financial obligations at maturity. Therefore, it is expected that there is a negative relationship between the two variables, liquidity ratios and financial distress. As for measuring the liquidity ratio in this study using a proxy measurement that is the current ratio. The formula for calculating the current ratio is (Hidayat \& Meiranto, 2014):

Current Ratio $=\frac{\text { Current Asset }}{\text { Current Liabilities }}$

\section{Rasio Leverage}

The ratio used to measure the level of a company's ability to meet all its obligations is called a leverage ratio. This ratio shows how much the company's assets are funded from debt. The high debt owned by the company, the company is forced to generate more income in order to pay debts and interest. Therefore, it is estimated that there is a positive relationship between leverage ratios and financial distress. As in this study the leverage ratio is measured using the total debt to asset ratio. The formula to calculate the total debt ratio is (Hidayat \& Meiranto, 2014):

Debt To Asset Ratio $=\frac{\text { Total Liabilities }}{\text { Total Asset }}$

\section{Profitability Ratio}

The company's ability to generate profits for a certain period is illustrated in the profitability ratio. The high profitability of a company will indicate that the company is able to generate high profits, so that the increase in assets will also occur and will keep the company away from the threat of financial distress. Therefore, it is estimated that there is a negative relationship between profitability ratios and financial distress. As in this study, profitability ratios are measured using return on assets (ROA). The formula for calculating return on assets is (Hidayat \& Meiranto, 2014):

Return On Asset $($ ROA $)=\frac{\text { Net Income }}{\text { Total Asset }}$

\section{Sales Growth}

Sales growth is a reflection of a company's ability to increase sales over time. By knowing how much sales growth, the company will be able to predict how much profit will be obtained. As in this study sales growth is measured using the formula (Widarjo and Setiawan, 2009: 11):

Sales Growth $=\frac{\text { Penjualan }(\mathrm{t})-\text { Penjualan }(\mathrm{t}-1)}{\text { Penjualan }(\mathrm{t}-1)}$

\section{Dependent Variable \\ Financial distress}

Platt and Platt (2002) state that financial distress is a stage of decline in financial conditions before bankruptcy occurs. In the study using the Altman analysis model (ZScore) to measure the financial health of the company and as a tool to predict the possibility of bankruptcy of a company. Following is the formula from the Altman Z-Score model (Hanafi, 2008)

$\mathrm{Z}=1,2 \mathrm{X} 1+1,4 \mathrm{X} 2+3,3 \mathrm{X} 3+0,6 \mathrm{X} 4+1,0 \mathrm{X} 5$

Keterangan:

$\mathrm{Z}=$ bankruptcy index

$\mathrm{X} 1=$ working capital / total assets

$\mathrm{X} 2=$ retained earnings / total assets

$\mathrm{X} 3$ = Profit before interest and tax $/$ total assets

$\mathrm{X} 4=$ market value of ordinary shares and preferred shares / book value of total debt

$\mathrm{X} 5=$ sales / total assets

Based on the value of $\mathrm{Z}$ generated, companies that are examined are then 
classified into three parts, namely, companies that are not bankrupt, companies that are vulnerable and potentially bankrupt companies (Hanafi, 2008). The assessment criteria used for company classification are as follows:

a. If the Z-Score > 2.99, the company is included in the category of a very healthy company so that it is classified as a company that is not bankrupt (Hanafi, 2008).

b. If the Z-Score $>1.81$ and $<2.99$, the company falls into the category of bankruptcy (Hanafi, 2008).

c. If the Z-Score $<1.81$ then, the company falls into the category of a bankrupt company (Hanafi, 2008)

\section{Data Types and Sources}

The data used in this study were sourced from secondary data obtained from the Indonesia Stock Exchange by looking at the 2012-2017 financial statement data through the website www.idx.co.id. The type of data used in this study entered into the type of ratio data where there are numbers with zeros that are considered absolute.

\section{Location and Research}

Object This research was conducted in Indonesia using secondary data in the form of financial statements of manufacturing sector companies listed on the Indonesia Stock Exchange (BEI) in 2012-2017. The reason the authors use manufacturing sector companies as research objects is because this sector is more dominant than other sectors, thus allowing the writer to get more samples.

\section{Number of Sample Determination Techniques}

The population in this study were 158 manufacturing sector companies listed on the Indonesia Stock Exchange (IDX) in
2012-2017. The author uses the opinion of Roscoe (2006) to determine the number of samples in this study. Roscoe (2006) states that a good sample consists of at least 30 samples and a maximum of 500 samples for each category. Based on this opinion, the authors will use a total sample of 81 companies that have been adjusted to the criteria that will be used in sampling. Sampling Technique The sampling technique in this study is non probability sampling with a purposive sampling method, where samples are taken based on consideration of certain criteria. The sample criteria in this study are as follows:

a. Manufacturing sector companies whose shares are still actively traded on the Indonesia Stock Exchange during 20122017.

b. Companies that report in Rupiah (Rp)

c. Publish annual financial statements for 2012-2017.

d. Having complete data related to the research variables.

The reason for using the purposive sampling method in this study, because the authors expect the samples obtained are representative and in line with the objectives of the study.

\section{Data collection technique}

Data collection techniques in this study is to use the archive technique in the database obtained from Indonesia Stock Excange, by collecting financial reports from companies in the manufacturing sector in the period 2012-2017. The data contains information related to Current Ratio (CR), Return On Assets (ROA), Debt to Asset Ratio (DAR), and Sales Growth. If the ratio information data is not presented directly, researchers can calculate the ratio using a formula.

\section{Data Processing Techniques}


In the data processing there are several steps that will be carried out by the authors including:

1. Researchers take data that will be processed from the sample company's financial statements. Among them, Current Ratio (CR), Return On Assets (ROA), Debt to Asset Ratio (DAR), and Sales Growth.

2. The data that has been collected is processed by entering into a table in Microsoft Excel.

3. Editing, which is checking the data to see if there is a bias in the data that must be corrected immediately.

4. Coding, which is making codes to facilitate data processing.

5. Processing data using computer facilities with the Eviews application program.

\section{Data Analysis Technique}

\section{Descriptive Statistical Analysis}

Descriptive statistical analysis is used to show overall research data, including the mean, median, variant, maximum, minimum, and standard deviation (Ghozali, 2012). Data that is tested and analyzed by this method is expected to produce data that are normally distributed.

\section{Panel Data Regression Analysis}

This study uses panel data with the aim of analysis that can be more comprehensive because the sample can be represented annually. Panel data also shows relationships between the current year and the previous year. The model used to perform panel data regression analysis consists of three, namely:

\section{Chow Test}

Chow Test aims to compare between common effects or fixed effects. Model selection can be done by taking into account the probability value (P-value). If the probability value produced is greater than the real level (alpha) then the model to be used in panel data regression is a common effect, otherwise if the probability value produced is smaller than the real level (alpha) then the model to be used in panel data regression is fixed effect (Widarjono, 2007).

\section{Hausman Test}

The Hausman test is performed after performing a chow test, the purpose of this test is to compare the fixed effects or random effects that are most appropriate for managing panel data regression. Model selection can be done by taking into account the probability value (P-value). If the probability value is small from the real level (alpha), then the model chosen is fixed effect, otherwise if the value is large, then the model chosen is random effect (Widarjono, 2007).

\section{Langrangge Multiplier Test (LM Test)}

Langrangge Multiplier test aims to determine whether the common effect model is better than the random effect model. Model selection can be done by comparing the Lmcount value with Chi Squared table with alpha 0.05 . If the Lmcount is greater than the Chi Squared table then the method to be used in the panel data regression is the random effect. Conversely, if the Lmcount value is smaller than the Chi Squared table then the method to be used in panel data regression is the common effect (Widarjono, 2007).

\section{Classical Assumption Test for Panel Data}

After the right panel data regression model is obtained, then test the classical assumptions. According to Nachrowi and Usman (2006), panel data regression data analysis does not require free from normality and auto correlation tests, therefore both tests are not necessary. In this study, testing the classical assumptions that 
are appropriate to be used in this study are as follows.

\section{Multicollinearity Test}

The multicollinearity test was used to show the linear relationship between the independent variables in the regression model. The purpose of using the multicollinearity test is to find the presence or absence of correlation between independent variables in the regression model. Regression models are said to be good if there is no correlation between independent variables. This can be seen from the value of tolerance or the value of VIF (Variance Inflation Factor), both of which indicate the size of each independent variable when explained by other independent variables. Decision making in this test uses that is, if the tolerance value is greater than 0.10, there will be no multicollinearity or if the VIF (Variace inflation factor) value is smaller than 0.10 , there will be multicollinearity and vice versa.

\section{Heteroscedasticity Test}

According to Sumodiningrat (2002), the heterokedasticity test was used with the aim of looking at the variance inequality of each residual in the regression model. Good data is if there is no heterokedastity or variant of variables in the constant value regression model (Homokedastisitas). Several methods can be used to detect the presence or absence of heterokedasticity. This study uses the glacier test, namely by regressing the independent variable with the absolute value of the residual. The conclusion drawing criteria are, if the correlation sig value is greater than $0.05 \quad(\mathrm{a}=5 \%)$, then heterocedasticity does not occur.

\section{Hypothesis Test}

Hypothesis testing is a provisional conjecture of something made to interpret a phenomenon, accept or reject a hypothesis. The hypothesis of this study is a one-tailed (one-tailed) test in which the direction of the hypothesis is known. The statistical method used in this study is multiple linear regression analysis, where there are four independent variables in this study and one dependent variable. According to Sugiyanto (2014: 277), multiple linear regression analysis will be conducted if the number of independent variables of the study is at least two. The multiple linear regression analysis equation model in this study is as follows (Sugiyono 2014: 277).

\begin{tabular}{ll}
\hline \multicolumn{1}{|c}{$\boldsymbol{Y}=\boldsymbol{a}+\boldsymbol{\beta 1} \boldsymbol{x}_{\mathbf{1}}+\boldsymbol{\beta 2} \boldsymbol{x}_{\mathbf{2}}+\boldsymbol{\beta} \mathbf{3} \boldsymbol{x}_{\mathbf{3}}+\boldsymbol{\beta} \mathbf{4} \boldsymbol{x}_{\mathbf{4}}+\epsilon$} \\
Keterangan : & \\
$\mathrm{Y}$ & $=$ Financial Distress \\
$\mathrm{a}$ & $=$ Constant Coefficient \\
$\beta 1, \beta 2, \beta 3, \beta 4$ & $=$ Regression Coefficient \\
$\mathrm{X} 1$ & $=$ Liquidity Ratio \\
$\mathrm{X} 2$ & $=$ Leverage Ratio \\
$\mathrm{X} 3$ & $=$ Profitability Ratio \\
$\mathrm{X} 4$ & $=$ Sales Growth \\
$\epsilon$ & $=$ Error
\end{tabular}

\section{Simultaneous Significance Test (Statistical Test F)}

Basically, the Statistical Test F is used to see how the influence of the independent variables on the dependent variable simultaneously (Ghozali I., 2012). This test is done by comparing the significant $\mathrm{F}$ calculation with $\mathrm{F}$ according to the table. The relationship between the two variables was tested using the following hypothesis: $\mathrm{H}_{0}=$ there is no linear relationship between the independent and dependent variables. $\mathrm{H}_{\mathrm{a}}=$ there is a linear relationship between the independent and dependent variables.

The decision making criteria in this test are: If the probability value ( $p$-value) $<$ alpha, then H1 is accepted so that it can be said that there is a significant influence between the independent variables simultaneously on the dependent variable. 
However, if the probability value ( $p$-value) $>$ alpha then $\mathrm{H} 0$ is rejected so that there is no significant effect between the independent variables on the dependent variable simultaneously.

\section{Partial Significant Test (Statistical Test t)}

Basically, the t-test statistic is used to see how the influence of the independent variables on the dependent variable individually (Ghozali I., 2012). This test is done by comparing the significant $t$ calculation with $\mathrm{t}$ according to the table by looking at the column of significance at each $t$ value. The relationship between the two variables was tested using the following hypothesis:

$\mathrm{H} 0=$ Partially the independent variable has no effect on the dependent variable.

$\mathrm{Ha}=$ Partially the independent variable influences the dependent variable.

Criteria for decision making in this test is that if the probability value ( $p$-value) $<$ alpha, then H1 is accepted so that it can be said that there is a significant influence between the independent variables on the dependent variable partially. However, if the probability value ( $\mathrm{p}$-value) $>$ alpha then $\mathrm{H} 0$ is accepted so that there is no significant effect between the independent variables on the dependent variable partially.

\section{RESULTS AND DISCUSSION Descriptive Statistics}

Table 4. 2 Descriptive Statistics

\begin{tabular}{lccccc}
\hline & N & Min & Max & Mean & Std. Dev. \\
\hline DAR & 480 & 0,33 & 1,52 & 2,88 & 2,14 \\
CR & 480 & 0,01 & 1,51 & 2,39 & 2,10 \\
ROA & 480 & $-0,54$ & 3,08 & 0,12 & 1,40 \\
SG & 480 & $-0,99$ & 9,80 & 0,26 & 0.75 \\
\hline
\end{tabular}

Note: This table presents the results of statistical tests. All results of each variable are in units. Independent Variable $(\mathrm{DAR}=$ Total Assets to Debt Ratio, $\mathrm{CR}=$ Current Ratio, ROA = Return on Assets, $\mathrm{SG}=$ Sales Growth)

Source: Processed Output Eviews 9
Berdasarkan hasil uji statistik deskriptif pada tabel 4.2 above, it can be seen that this study has 480 observational data which are the overall data from 2012 to 2017.

The independent variable is an indicator of financial ratios consisting of leverage ratios, liquidity ratios, profitability ratios, and sales growth. Leverage ratios are measured using Total Debt Asset Ratio (DAR) that is total liabilities divided by total assets. The average value of DAR is 2.881015, which indicates that manufacturing companies in Indonesia for the period 2012-2017 have an average level of debt control over total assets. The maximum value shows the total value of the total debt asset ratio of manufacturing companies at 1.528506 while the lowest value is 0.330133 indicating the value of the total debt asset ratio in manufacturing companies. The standard deviation or inequality value of 2.148062 indicates the average deviation of the total debt asset ratio.

Liquidity ratios are measured using Current Ratio (CR), i.e. current assets divided by current liabilities. Current Ratio has an average value of 2,391709, which indicates that manufacturing companies in Indonesia for the period of 2012-2017 have an average level of ability of a company to meet its financial obligations at maturity. The maximum value indicates the current ratio value of manufacturing companies at the highest of 1.516460 while the lowest value of 0.013956 indicates the value of the current ratio at manufacturing companies. The standard deviation value or inequality of 17.6111 shows the average deviation of the current ratio.

Profitability ratios are measured using Return on Assets (ROA), which is net income divided by total assets. Return on Assets has an average value of 0.122545 , indicating that manufacturing companies in Indonesia for the period 2012-2017 have an 
average level of the company's ability to generate net income at a certain level of asset levels. The maximum value shows the highest value of return on assets of manufacturing companies at 3.080469 while the lowest value of -0.548466 shows the value of return on assets of manufacturing companies. The standard deviation or inequality value of 1.408096 shows the average deviation of return on assets.

Sales growth is measured by the formula that this year's sales minus previous year's sales divided by previous year's sales. Sales Growth has an average value of 0.262021 , indicating that manufacturing companies in Indonesia for the period 20122017 have an average level of ability of companies to use their assets to support sales activities. The maximum value indicates the highest Sales Growth value of manufacturing companies at 9.804008 while the lowest value is -0.999999 showing the value of Sales Growth in manufacturing companies.

\section{Chow Test (F test)}

Chow test is performed to compare or choose the best regression model between common effect and fixed effect using the $\mathrm{F}$ test (chow test), where the significance level is 0.05 . The following $F$ test results (chow test) can be seen in table as follows:

Tabel 4.3 Chow Test Results

\begin{tabular}{lllll}
\hline \hline Variabel Effect Test & Statistic & d.f & Prob. \\
\hline \hline DAR & $\begin{array}{l}\text { Cross- } \\
\text { section F }\end{array}$ & 8.481 .324 & $(79,399)$ & 0.0000 \\
CR & $\begin{array}{l}\text { Cross- } \\
\text { section F }\end{array}$ & 8.978 .435 & $(79,399)$ & 0.0000 \\
ROA & $\begin{array}{l}\text { Cross- } \\
\text { section F }\end{array}$ & 9.618 .668 & $(79,399)$ & 0.0000 \\
SG & $\begin{array}{l}\text { Cross- } \\
\text { section F }\end{array}$ & 9.634 .331 & $(79,399)$ & 0.0000 \\
\hline
\end{tabular}

\section{Source: Processed Output Eviews 9}

Based on the table above the magnitude of the cross-section probability $F$ on the Debt Asset Ratio (DAR), current ratio (CR), Return On Asset (ROA), and sales growth $(\mathrm{SG})$ variables are all 0.0000 . The cross-section probability value of $\mathrm{F}<0.05$, the results of the $\mathrm{F}$ test (chow test) indicate that the fized effect model is more appropriate than the common effect model for each variable. Then the hausman test will then be conducted.

\section{Hausman Test}

The Hausman Test Method is performed to compare or choose which model is the best between fixed effects and random effects by using the Hausman test, where the significance level is 0.05 . Following hausman test results can be seen in table 4.4, as follows:

Tabel 4.4 Hausman Test Results

\begin{tabular}{|c|c|c|c|c|}
\hline Hipotesis & $\begin{array}{c}\text { Test } \\
\text { Summary }\end{array}$ & $\begin{array}{c}\text { Chi- } \\
\text { Sq.Statistic }\end{array}$ & $\begin{array}{c}\text { Chi-Sq. } \\
\text { d.f. }\end{array}$ & Prob. \\
\hline DAR & $\begin{array}{l}\text { Cross- } \\
\text { section } \\
\text { Random }\end{array}$ & 0.1931 & 1 & 0.0403 \\
\hline CR & $\begin{array}{l}\text { Cross- } \\
\text { section } \\
\text { Random }\end{array}$ & 0.9536 & 1 & 0.0328 \\
\hline ROA & $\begin{array}{l}\text { Cross- } \\
\text { section } \\
\text { Random }\end{array}$ & 0.5606 & 1 & 0.0450 \\
\hline SG & $\begin{array}{l}\text { Cross- } \\
\text { section } \\
\text { Random }\end{array}$ & 0.0562 & 1 & 0.0125 \\
\hline
\end{tabular}

\section{Source: Processed Output Eviews 9}

Based on the table above the magnitude of the random cross-section probability on the variable Debt Asset Ratio (DAR), current ratio (CR), Return On Assets (ROA), and sales growth (SG) respectively $0.0403,0.0328,0.0450$, and 0.0125 . The random cross-section probability value 
$<0.05$, the results of the hausman test indicate that the Fixed effect (FE) model is more appropriate to use for the regression equation model than the Random effect model for each variable.

\section{Classic Assumption Test}

Multicollinearity Test

Based on the results of Table 4.5, it is seen that there is no multicollinearity problem between the independent variables because the value of each variable is smaller than 0.8 (correlation $<0.8$ ).

Table 4.5 Multicollinearity Test

\begin{tabular}{lcccc}
\hline & DAR & CR & ROA & SG \\
\hline DAR & 1,0000 & 0,7515 & 0,0152 & $-0,0399$ \\
CR & 0,7515 & 1,0000 & 0,0125 & -0.0482 \\
ROA & 0,0152 & 0,0125 & 1,0000 & 0,0384 \\
SG & $-0,0399$ & $-0,0482$ & 0,0384 & 1.0000 \\
\hline \multicolumn{5}{c}{ Source: Processed Output Eviews 9 }
\end{tabular}

\section{Heteroscedasticity Test}

From table 4.6 shows that the value of Obs * R-Squared is 4.269 .526 while the probability value is $0.3708>0.05$, it can be concluded that the data do not experience heteroscedasticity problems.

Table 4.6 Heteroscedasticity Test

Heteroskedasticity Test: White

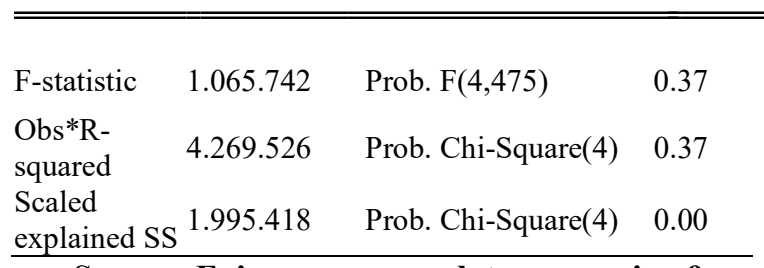

Source: Eviews program data processing 9

\section{Hypothesis Testing}

\section{Liquidity Ratio has a positive influence} on the prediction of financial distress. (H1)

Based on Eviews testing to determine the right regression model Chow Test and Hausman Test a good regression model used in hypothesis 1 is Fixed effect. The regression output used can be seen in table 4.7 as follows:

Tabel 4.7 Test Results of Fixed Effect Model

\begin{tabular}{lccc}
\hline \multicolumn{1}{c}{ Variable } & Coefficient & t-Statistic & Prob. \\
\hline $\mathrm{C}$ & 4.097 .151 & 9.834 .694 & 0.0000 \\
$\mathrm{CR}$ & 0.389760 & 2.416 .493 & 0.0161 \\
R-squared & 0.661063 & & \\
Adjusted R- & 0.593106 & & \\
squared & & & \\
\hline
\end{tabular}

Source: Eviews program data processing 9

Based on the results of the Eviews output in table 4.7 above, the regression equation model can be made as follows:

\begin{tabular}{c|}
\hline$Z_{i t}=\alpha+\beta_{1} C_{R_{i t}}+\varepsilon_{i t}$ \\
\hline$Z_{i t}=4.097 .151+0.389760 C R_{i t}+\varepsilon_{i t}$ \\
\hline
\end{tabular}

The results of the Fixed effect model show that the $\mathrm{CR}$ variable regression coefficient value of 0.389760 with $t$ equal to 2.416 .493 and the significance of 0.0161 $<0.05$ this indicates that $\mathrm{H} 1$ is supported so that it can be concluded that CR has a positive and significant effect on Financial Distress. R-squared value of 0.661063 or $66 \%$ indicates that the $\mathrm{CR}$ variable can explain the dependent variable at $66 \%$ while the remaining $34 \%$ can be explained by other variables not included in the model.

\section{Leverage Ratios have a positive influence on financial distress predictions. (H2)}

Based on Eviews testing to determine the right regression model using the Chow Test and Hausman Test a good regression model used in hypothesis 2 is Fixed effect. The regression output used can be seen in table 4.8 as follows:

Tabel 4.8 Test Results of the Fixed Effect Model

\begin{tabular}{lccc}
\hline \multicolumn{1}{c}{ Variable } & Coefficient & t-Statistic & Prob. \\
\hline C & 7.452 .076 & 1.063 .264 & 0.0000 \\
DAR & 4.709 .021 & 3.545 .723 & 0.0004 \\
R-squared & 0.666608 & & \\
Adjusted & 0.599762 & & \\
R-squared & & & \\
\hline
\end{tabular}

Source: Eviews program data processing 9

Based on the results of the Eviews output in table 4.8 above, the regression equation model can be made as follows: 
$Z_{i t}=7.452 .076+4.709 .021 D A R i t+\varepsilon_{i t}$

The results of the Fixed effect model show that the DAR variable regression coefficient of $4,709,021$ with $t$ equal to $3,545,723$ and a significance of 0.0004 $<0.05$ this indicates that $\mathrm{H} 2$ is supported so it can be concluded that DAR has a positive and significant effect on Financial Distress. R-squared value of 0.666608 or $66 \%$ indicates that the $\mathrm{CR}$ variable is able to explain the dependent variable by $66 \%$ while the remaining $34 \%$ can be explained by other variables not included in the model.

\section{Profitability Ratios have a negative influence on financial distress predictions. (H3)}

Based on Eviews testing to determine the right regression model using the Chow Test and Hausman Test a good regression model used in hypothesis 3 is Fixed Effect. The regression output used can be seen in table 4.9 as follows:

Tabel 4.9 Model Test Results Fixed Effect

\begin{tabular}{llll}
\hline Variable & Coefficient & t-Statistic & Prob. \\
\hline C & 5.025 .439 & 3.157 .509 & 0.0000 \\
ROA & 0.031855 & 0.258134 & 0.7964 \\
R-squared & 0.656160 & & \\
Adjusted & & & \\
R-squared & 0.587220 & & \\
\hline
\end{tabular}

Source: Eviews program data processing 9

Based on the results of the Eviews output in table 4.9 above, the regression equation model can be made as follows:

$Z_{i t}=\alpha+\beta 3 R_{1} A_{i t}+\varepsilon_{i t}$

$$
Z_{i t}=5.025 .439+0.031855 R_{\text {RAit }}+\varepsilon i t
$$

The results of the Fixed effect model show that the regression coefficient of the variable ROA of 0.031855 with $t$ of 0.258134 and the significance of $0.7964>$ 0.05 , this shows that $\mathrm{H} 3$ is not supported so it can be concluded that ROA has no effect on Financial Distress and shows a positive direction. R-squared value of 0.656160 or $65 \%$ indicates that the $\mathrm{CR}$ variable is able to explain the dependent variable by $65 \%$ while the remaining $35 \%$ can be explained by other variables not included in the model.

\section{Sales Growth Has A Negative Influence On Financial Distress Predictions (H4)}

Based on Eviews testing to determine the right regression model using the Chow Test and Hausman Test a good regression model used in hypothesis 4 is Fixed Effect. The regression output used can be seen in table 4.10 as follows:

Table 4.10 Fixed Effect (H4) Model Test Results

\begin{tabular}{lccc}
\hline Variable & Coefficient & t-Statistic & Prob. \\
\hline C & 5.038 .498 & 2.980 .731 & 0.0000 \\
SG & -0.034941 & -0.155473 & 0.8765 \\
R-squared & 0.656123 & & \\
Adjusted & 0.587176 & & \\
R-squared & & & \\
\hline
\end{tabular}

Source: Eviews program data processing 9

Based on the results of the Eviews output in table 4.10 above, the regression equation model can be made as follows:

\begin{tabular}{|c|}
$Z_{i t}=\alpha+B_{3} S_{i t}+\varepsilon_{i t}$ \\
\hline$Z_{i t}=5.038 .498-0.034941 S G_{i t}+\varepsilon_{i t}$ \\
\hline
\end{tabular}

The results of the Fixed effect model show that the regression coefficient value of Sales Growth (SG) of -0.034941 with t of 0.155473 and the significance of $0.8765>$ 0.05 , this indicates that $\mathrm{H} 4$ is not supported so it can be concluded that Sales Growth (SG) has no effect on Financial Distress and shows the negative direction. R-squared value of 0.656123 or $65 \%$ indicates that the $\mathrm{CR}$ variable is able to explain the dependent variable by $65 \%$ while the remaining $35 \%$ can be explained by other variables not included in the model.

Liquidation Ratios, Leverage Ratios, Profitability Ratios and Sales Growth have an influence on the prediction of financial distress. (H5) 
Based on the Eviews test to determine the right regression model using the Chow Test and the Hausman Test a good regression model used to test this hypothesis 5 is simultaneously the Fixed Effect. The regression output used can be seen in table 4.11 as follows:

Table 4.11 Random Test Model Results (H5)

\begin{tabular}{llll}
\hline Variable & Coefficient & t-Statistic & Prob. \\
\hline $\mathrm{C}$ & 6.588 .355 & 6.921 .261 & 0.0000 \\
$\mathrm{CR}$ & 0.229350 & 1.352 .826 & 0.1769 \\
DAR & 4.083 .647 & 2.901 .838 & 0.0039 \\
ROA & 0.029844 & 0.244927 & 0.8066 \\
SG & -0.039006 & -0.175738 & 0.8606 \\
R-squared & 0.668208 & & \\
F-statistic & 9.608 .677 & & \\
$\begin{array}{l}\text { Prob(F- } \\
\text { statistic) }\end{array}$ & 0.000000 & & \\
\hline
\end{tabular}

Sumber: Hasil olah data program Eviews 9

Based on the results of the Eviews output in Table 4.11 above, the regression equation model can be made as follows:

$Z_{i t}=\alpha+\beta_{1} C R_{i t}+\beta_{2} D A R_{i t}+\beta_{3} R O A_{i t}+\beta_{4} S G_{i t}+\varepsilon_{i t}$

$Z_{\text {it }}$ 6.588.355 $+0.229350 C R_{\text {it }}+4.083 .647 D A R_{\text {it }}$ $+0.029844 R O A_{i t}-0.039006 S_{i t}+\varepsilon_{i t}$

The results of the Fixed effect model show that the value of f-Statistics on all variables, namely, Current Ratio (CR), Debt Asset Ratio (DAR), Return On Assets (ROA), and Sales Growth (SG) tested simultaneously show a figure of 9,608.677 and significance of $0.000000<0.05$, this shows that H5 is supported so that it can be concluded that the Current Ratio (CR), Debt Asset Ratio (DAR), Return On Assets (REDS5OA), and Sales Growth (SG) affect the Financial Distress. R-squared value of 0.668208 or $66 \%$ indicates that all independent variables namely, Current Ratio (CR), Debt Asset Ratio (DAR), Return On Asset (ROA), and Sales Growth (SG) are able to explain the dependent variable by $66 \%$ while the remaining $34 \%$ can be explained by other variables not included in the model.

\section{DATA ANALYSIS}

The following is a summary table of the results of a research hypothesis test on manufacturing companies listed on the Indonesia Stock Exchange for the period 2012-2017.

Table 4.12 Summary of Hypothesis Test Results

\begin{tabular}{lllll}
\hline No. & Hip. & Sig. & t-Statistik & Conclusion \\
\hline \hline 1 & H1 & 0.0161 & 2.416 .493 & supported \\
2 & H2 & 0.0004 & 3.545 .723 & supported \\
3 & H3 & 0.7964 & 0.258134 & unsupported \\
4 & H4 & 0.8765 & -0.155473 & unsupported \\
5 & H5 & 0.0000 & 9.608 .677 & supported \\
\hline \multicolumn{5}{c}{ significant at the level 5\% $(\boldsymbol{\alpha}=\mathbf{0 . 0 5})$}
\end{tabular}

Source: Eviews program data processing 9

\section{Rasio Likuidasi Memiliki Pengaruh Positif Terhadap Kondisi Financial Distress.}

Based on the results of the hypothesis 1 test described in table 4.7 shows that the probability value of the current ratio is $0.0005<0.05(\alpha=5 \%)$ and the coefficient is positive $(\mathrm{t}=2.416 .493)$, which means that the liquidity ratio measured by the current ratio significantly positive effect on the prediction of financial distress. These results indicate a relationship that is directly proportional between the independent variable and the dependent variable. This means that the greater the company's ability to finance debt, the greater the possibility of financial distress. This is usually seen from how much the company placed a large amount of funds on the side of current assets to meet short-term obligations that are due soon. The results of this study are strengthened by research conducted by Nurhidayah and Fitriyatur (2017), which states that there is a positive influence of the variable Liquidity on financial distress. In addition, this study was also strengthened by 
the results of research conducted by Muska, N. M. (2016). which explains that Current Ratio has a positive influence on financial distress.

\section{Leverage Ratio Has A Positive Influence On Financial Distress.}

Based on the results of the DAR hypothesis test or Debt Asset Ratio to Financial Distress shows that the value of the probability of Debt Asset Ratio is 0.0004 $<0.05(\alpha=5 \%)$ and the coefficient is positive $(\mathrm{t}=3,545,723)$, which means that the current ratio significantly influences positive predictions of financial distress. These results indicate a relationship that is directly proportional between the independent variable and the dependent variable. This means that if the intensity of the use of debt in funding a company is getting bigger, then the possibility of financial distress will be even greater.

This is usually seen from how much a company's ability to meet all its obligations, both in the short term and long term. The results of this study are in line with research conducted by Ahmad (2011), showing that leverage ratios significantly have positive implications for financial distress in a company when measured by using Debt to Asset Ratio (DAR). In contrast to research conducted by Muska, N. M. (2016) which states that Debt to Asset Ratio (DAR) has no influence on financial distress.

\section{Profitability Ratios Have A Negative Influence On Financial Distress.}

Based on the results of hypothesis testing ROA or Return On Investments against Financial Distress shows that $\mathrm{H} 3$ is not supported by the probability of Return On Investment $0.7964>0.05(\alpha=5 \%)$ and the coefficient is positive $(\mathrm{t}=0.258134)$, meaning ROA or Return On Investment does not affect the prediction of financial distress. The results of this study differ from previous studies conducted by Nurhidayah and Fitriyatur (2017) which state that Return On Assets (ROA) has a significant positive effect on financial distress. This study is also different from the results of research conducted by Baimwera \& Muriuki (2014) which shows that profitability ratios have a significant effect on financial distress. This is due to the low level of the company's ability to generate profits, when viewed from the overall average year.

The results of this study are the same as research conducted by Lucyanda and Lilyana (2012) which states that the profitability ratio measured by return on assets does not affect the prediction of financial distress. The results of this study are in line with research conducted by Hidayat \& Meiranto (2014) which states that the profitability ratio does not significantly influence the likelihood of financial distress in a company.

\section{Sales Growth Has A Negative Influence On Financial Distress.}

Based on the results of hypothesis 4 test that has been described in table 4.11 shows that there is no significant effect and negative direction between sales growth and financial distress variables. This can be proven by the probability value of $0.8765>$ $0.05(\alpha=5 \%)$ and the coefficient value is negative $(\mathrm{t}=-0.155473)$, meaning that hypothesis 4 is unsupported and has no effect on financial distress prediction. The results of this study differ from previous studies conducted by Nurhidayah and Fitriyatur (2017) which state that Return On Assets (ROA) has a significant positive effect on financial distress. This research is also different from the results of research conducted by Baimwera \& Muriuki (2014) which shows that sales growth has a significant effect on financial distress. This is due to the low level of sales growth, if seen from the overall average year. However, research in line with this was 
conducted by Nugroho, E. (2017) and research conducted by Liana and Sutrisno (2014) which showed that sales growth had no effect on financial distress.Rasio likuiditas, rasio leverage, rasio proitabilitas dan pertumbuhan penjualan (Sales Growth ) memiliki pengaruh terhadap kondisi financial distress.

Based on the results of the hypothesis 5 test that has been described in table 4.12 shows that simultaneously there is a significant influence between variable liquidity ratios, leverage ratios, profitability ratios, sales growth and financial distress. This can be proven by the probability value of $0.0000>0.05(\alpha=5 \%)$ and the coefficient value is positive $(\mathrm{t}=-9,608,677)$, meaning that hypothesis 5 is supported and simultaneously has a positive effect on financial distress prediction.

\section{CONCLUSIONS AND SUGGESTIONS Conclusions}

This study aims to examine the effect of financial ratio on the company's financial distress. The observation period in this study was 2012-2017 with 80 manufacturing sector companies being used as research samples. Based on the results of the analysis in Chapter 4, the following conclusions can be drawn:

1. Based on the results of research in hypothesis 1: there is a positive effect between the liquidity ratio measured by the current ratio to the prediction of financial distress. These results indicate a relationship that is directly proportional between the independent variable and the dependent variable. This means that the greater the company's ability to finance debt, the smaller the possibility of financial distress.

2. Based on the results of the study in hypothesis 2 : there is a positive influence between the leverage ratio measured by the debt asset ratio to the prediction of financial distress. These results indicate a relationship that is directly proportional between the independent variable and the dependent variable. This means that if the intensity of the use of debt in funding a company is getting bigger, then the possibility of financial distress will be even greater.

3. Based on the results of the study in hypothesis 3: there is no influence between the profitability ratio variable on the prediction of financial distress. This shows that the level of the company's ability to generate profits for a certain period will not affect the company's financial distress predictions.

4. Based on the results of research in hypothesis 4: there is no influence between sales growth variables on the prediction of financial distress. This shows that the level of the company's ability to a company's ability to increase sales over time will not affect the company's financial distress predictions.

5. Based on the results of research in Hypothesis 5: simultaneously there is an influence between liquidity ratios, leverage, profitability and sales growth on Financial distress

\section{BIBLIOGRAPHY}

Aisyah, N. N., Kristanti, F. T., \& Zultilisna, D. (2017). Pengaruh Rasio Likuiditas, Rasio Aktivitas, Rasio Profitabiltas,. $e$ Proceeding of Management : Vol.4, No.1, 412.

Alfifah, M., N. Salamudin, \& I. Ahmad. (2013). Prediction of Financial Distress Companies in the Consumer Product Sector in Malaysia. Jurnal Teknologi, 64(1), 85-91.

Almilia, L. S., \& Kristijadi, E. (2003). Analisis Rasio Keuangan untuk Memprediksi Kondisi Financial Distress Perusahaan Manufaktur yang 
terdaftar di BEJ. Jurnal Akuntansi dan Auditing Indonesia, 7(2), 1-27.

Altman, E. I. (1968). Financial Ratios, Discriminant Analysis and The Prediction of Corporate Bankcruptcy. The Journal of Finance, 23(4), 598608.

Atmaja, L. S. (2008). Teori \& Praktik Manajemen Keuangan . Yogyakarta: ANDI Yogyakarta.

Baimwera, B., \& Muriuki, A. M. (2014). Analisys Of Corporate Financial Distress Determinants: A Survei Of Non-Financial Listed In The NSE. International Journal of Current Business and Social Sciences, 1 (2), 58-80.

Brigham, E., \& Houston, J. (2014). DasarDasar Manajemen Keuangan Buku 1 Edisi 11. Jakarta: Salemba Empat.

Ghozali, I. (2011). Aplikasi Analisis Multivariat dengan Program SPSS. Semarang: Badan Penerbit Universitas Diponegoro.

Gujarati, D. N. (2012). Dasar Dasar Ekonometrika. Jakarta: Salemba Empat.

Hanafi, M. M. (2008). Manajemen Keuangan (1 ed.). Yogyakarta: BPFE Yogyakarta.

Hapsari, E. I. (2012). Kekuatan Rasio Keuangan Dalam Memprediksi Kondisi Financial Distress Perusahaan Manufaktur di Bursa efek Indonesia. Jurnal Dinamika Manajemen, 3(2), 101-109.

Hartono, J. (2014). Metodologi Penelitian Bisnis Salah Kaprah dan Pengalaman-Pengalaman (6 ed.). Yogyakarta: BPFE Yogyakarta.

Hidayat, M. A., \& Meiranto, W. (2014). Prediksi Financial Distress Perusahaan Manufaktur di Indonesia. Diponegoro Journal of Accounting, 3(3), 1-11.

Jansen, M. C., \& Meckling, W. H. (1976). Theory of the Firm: Managerial
Behavior,Agency Cost, and Ownership Structure. Journal of Financial and Economics, 3(4), 305360.

Jiming, \& Wei Wei. (2011). An Empirical Study on the Corporate Financial Distress Prediction Based on Logistic Model Evidence from China's Manufacturing Industry. International Journal of Digital Content Technology and its Application, 5(6), 368-379.

Liana, D., \& Sutrisno. (2014). Analisis Rasio Keuangan Untuk Memprediksi Kondisi Financial Distress Perusahaan Manufaktur. Jurnal Studi Manajemen dan Bisnis Vol 1, Vol 1, 2.

Muska, N. M. (2016). Pengaruh Profitabilitas, Likuiditas, Leverage Terhadap Prediksi Financial Distress. Institutional respositories \& scientific journals.

Nella, R. (2011). Analisis Rasio Keuangan dalam Memprediksi Financial Distress Perusahaan Wholesale dan Retail Trade yang Terdaftar di Bursa Efek Indonesia . Journal of accounting, 114.

Nugroho, E. (2017). Analisis Pengaruh Likuiditas, Pertumbuhan Penjualan, Perputaran Modal Kerja, Ukuran Perusahaan, dan Leverage Terhadap Profitabilitas. Semarang: Fakultas Ekonomi Universitas Diponegoro.

Platt, H., \& Platt, M. (2002). Predicting Corporate Financial Distress: Reflections on Choice Based Sample Bias. Journal of Economics and Finance, 26(2), 184-197.

Sartono, A. (2008). Manajemen Jeuangan Teori dan Aplikasi Edisi 4. Yogyakarta: BPFE-Yogyakarta.

Sugianto, M., \& Community, S. (2012). Mengolah Data Bisnis dengan SPSS 20. Jakarta: PT Elex Media Komputindo. 